\author{
Anna Gierusz \\ Uniwersytet Gdański \\ e-mail: anna.gierusz@ug.edu.pl
}

\title{
SETTING A MINIMUM BENEFIT AMOUNT IN A DC WITH AN UNDERPIN OCCUPATIONAL PENSION SCHEME
}

\section{OKREŚLENIE MINIMALNEJ WYSOKOŚCI ŚWIADCZENIA W PRACOWNICZYM PROGRAMIE EMERYTALNYM DC Z MINIMALNYM ŚWIADCZENIEM}

DOI: $10.15611 / \mathrm{pn} .2018 .541 .04$

JEL Classification: G22, J32

Summary: In a defined contribution pension scheme risk of an unknown benefit amount is borne by the member. To allow for the risk to be shared between the member and the employer a DC with an underpin can be used. Minimum benefit amount is set in this scheme in advance. Two methods of setting this minimum will be investigated. The first option specifies a minimum benefit amount, calculated given an annual rate of return which should be credited over the whole period of scheme membership. The second one assumes that a minimum rate of return has to be applied to the member's account every year. The aim of this paper is to compare these two possibilities from the member's and employer's point of view. Benefit amount, extra employer contribution amount and frequency were selected as the criteria. It was shown that the second method results in a higher member benefit amount. However, it requires higher and more frequent contributions from the employer.

Keywords: occupational pension scheme, DC with an underpin, hybrid pension scheme, minimum benefit.

Streszczenie: Programy emerytalne o zdefiniowanej składce charakteryzują się nieznaną wysokością świadczenia. Ryzyko z tym związane ponosi uczestnik. Aby umożliwić podział ryzyka pomiędzy pracodawcę i uczestnika, można wprowadzić program DC z minimalnym świadczeniem. W artykule zbadane zostały dwie metody określenia minimalnej wysokości. Pierwsza zakłada, iż w ciągu całego okresu uczestnictwa stopa zwrotu z inwestycji odnotowana na koncie uczestnika powinna być nie mniejsza niż z góry założone minimum. W przypadku drugiej opcji stopa zwrotu z inwestycji musi być co roku wyższa niż określone minimum. Celem artykułu jest porównanie dwóch metod z punktu widzenia uczestnika oraz pracodawcy. Jako kryteria przyjęto wysokość świadczenia uczestnika, wysokość dodatkowych wpłat pracodawcy oraz ich częstotliwość. Wykazano, iż druga metoda skutkuje średnio wyższym świadczeniem uczestnika, ale wymaga od pracodawcy wyższych wpłat. W przypadku pierwszej natomiast rzadziej wymagane są dodatkowe wpłaty pracodawcy.

Słowa kluczowe: pracownicze programy emerytalne, programy o zdefiniowanej składce, programy hybrydowe, minimalna wysokość świadczenia. 


\section{Introduction}

In many countries the form of occupational pension schemes has been changing. Initially popular defined benefit (DB) schemes are being closed down and replaced with defined contribution (DC) schemes [Clark, Monk 2006]. DB schemes are an attractive form from the member's point of view as the benefit amount is defined in advance and the employer, as a sponsor of such a scheme, guarantees that the set benefit will be paid to the member for life. However, rising and variable cost of financing these benefits has caused many employers to close their DB schemes and opt for a DC scheme instead [Blommestein et. al. 2009, p. 66; Turner, Hughes 2008]. Such a solution transfers risk of financing benefits to the member. The employer has no obligation except for a payment of predefined contributions, hence the attractiveness from the employer's point of view. However, as the members may lack sufficient financial knowledge to insure themselves against risk present in the scheme, the solution is not without its flaws [Davis 2013, p. 685]. In response to the problem of risk sharing many hybrid schemes were created. These schemes are not a fully DB or a fully DC scheme, but combine features of both.

In this paper a type of hybrid scheme which was created by modifying a traditional DC scheme will be investigated. It is referred to as a DC scheme with an underpin, or a DC scheme with a minimum benefit amount [Wesbroom, Reay 2005, p. 15; Pugh, Yermo 2008, p. 8-9; Szczepański, Brzęczek 2016, p. 113; Turner 2014, p. 26]. Its rules are similar to a traditional DC scheme. Each member has an account into which employer's and member's contributions are paid. Funds accumulated within the account are invested, and investment returns are added to the account value. In a traditional DC scheme funds accumulated within the account are paid out as a benefit at the point of member's retirement. Depending on a regulation of a country the benefit can take form of a lump sum payment or can be transferred to an insurance company and used to purchase an annuity. However, in the DC with an underpin scheme the benefit which was achieved in this way is compared with the specified minimum, and the member receives the higher of the two. There are many different ways in which the minimum can be set. One of them defines the minimum benefit amount in advance in a way similar to the one used in a DB scheme. For example, the minimum account value at retirement could be specified, or the minimum pension amount could be set. Such a solution is used in Iceland, where the regulation states that the minimum benefit amount has to be equal to on average $1.4 \%$ of salary for each year of membership. Given 40 years of membership this translates to a benefit equal to around $56 \%$ of salary [Guðmundsson et. al 2014, p. 10]. A different way is to set a minimum rate of investment returns that has to be credited to the member's account every year. The law in Switzerland states such a rate every year or every couple of years. Since January 2017 it is set at 1\% [Credit Suisse 2018]. In this paper, these two methods will be investigated and compared. 


\section{Methods and assumptions}

In the article two methods of defining the underpin in a DC scheme were modelled. The first one assumes that the rate of investment returns which has been credited to the member's account should not be lower than a specified annual minimum rate. However, this minimum is not applied every year, but over the whole period of membership. At the point of member's retirement the amount accumulated in their account is compared with an amount that would have been accumulated has the investment rate been equal to the set minimum. The member receives the higher of the two amounts. As a result, the actual investment rate credited to the member's account does not need to be greater than the required minimum every year, but over the whole period of membership the returns have to provide a value greater than that which would have been achieved has the rate been equal to the minimum every year.

The second option defines the minimum rate of return that has to be credited to the member's account every year. In contrast to the first method, the actual rate of return is compared with the required minimum every year rather than just at the point of member's retirement. If the actual rate of return is below the minimum extra funds will be credited to the account.

In order to compare the two methods models of DC pension schemes with an underpin have been constructed, one for each of the two possibilities of defining the underpin. These allow to calculate benefit amounts received by the member, as well as extra contribution amounts payable by the employer.

It was assumed that there is a single member in each scheme, who joins the scheme aged 25, pays contribution for forty years and retires aged 65. Initial salary is equal to 4000 PLN per month (about the average salary in Poland in 2017 [GUS 2018]) and the annual rate of salary increase equals $1 \%$. The contribution rate paid into the pension scheme is equal to $3.5 \%$ of salary ${ }^{1}$, the proposed minimum contribution rate in new occupational pension schemes in Poland due to be introduced in 2019 [Instytut Emerytalny 2018, p. 11]. The assumptions are summarized in Table 1.

Table 1. Assumptions used in calculations

\begin{tabular}{|l|c|}
\hline \multicolumn{1}{|c|}{ Parameter } & Value \\
\hline Member's age on joining the scheme & 25 \\
\hline Member's retirement age & 65 \\
\hline Monthly initial salary of the member & 4000 PLN \\
\hline Annual rate of salary increase & $1 \%$ \\
\hline Contribution as a percentage of salary & $3.5 \%$ \\
\hline Mean annual rate of investment returns & $3 \%$ \\
\hline
\end{tabular}

Source: own work.

${ }^{1}$ This rate will be split between the member and the employer, with the former paying $2 \%$ and the latter $1.5 \%$ of salary. 
For the first hybrid scheme it is assumed that the annual rate of return applicable over the whole period of membership has to be equal to $3 \%$, the mean rate of returns. For the fixed contribution rate and salary increase rate shown in table 1 the amount accumulated in the account at the point of member's retirement has to be at least 148947 PLN. If it is lower the employer needs to pay additional contributions in order to reach the minimum. This can be done by paying additional one-off contribution at the very end of accumulation phase when the member retires. However, at this point the extra one-off contribution amount required can be very high. In order to spread the contribution over several years it is assumed that during the accumulation phase the employer monitors the value of the member's account. Every year a projection of the member's account value at retirement is performed based on the funds already accumulated, future contributions and expected future investment returns. If this projection shows that the minimum amount is not going to be achieved, the employer pays additional contribution into a separate fund. This additional contribution is calculated in a way which will allow the separate fund, in addition to the member's account, to achieve the minimum amount required.

In the second scheme the minimum rate of investment returns, applicable every year, is assumed to be $0 \%$. Hence every year the investment rate of return credited to the member's account cannot be negative. If the actual rate of return was negative, the employer would need to pay additional contributions into the account in order to boost the credited rate of return to $0 \%$.

It is assumed that the actual annual rate of investment returns achieved by the scheme is a random variable following a normal distribution with mean equal to $3 \%$ and standard deviation equal to $8 \%$. Forty rates (one for each year of scheme membership) were drawn from the assumed distribution and benefit amount as well as extra employer contribution amounts were calculated for both schemes.

\section{Results}

\subsection{Two scenarios}

In order to illustrate the difference between the two hybrid schemes two scenarios were considered. In the first scenario, called the moderate one, the actual investment rates (drawn at random from normal distribution with mean 3\%) were in line with expectations, as their average equalled to $3.4 \%$. Benefit amount from a traditional DC scheme with no underpin was equal to 168008 PLN. This was also the benefit amount which was paid out from the first hybrid scheme, as this value was higher than the minimum amount set at 148947 PLN. However, since there were three years when the projected benefit amount was less than this minimum, some additional contributions were paid by the employer. Fig. 1 presents the projected and required account value in the first hybrid scheme, as well as extra contributions paid by the employer. 




$1 \quad 3 \quad 5 \quad 7 \quad 9111315171921232527293133353739$

Scheme year

\section{Extra employer contribution — Projected account value \\ - Required account value}

Fig. 1. Projected and required account value and extra contributions paid by the employer in the first hybrid scheme in each scheme year for the moderate scenario

Source: own work.

As shown in Fig. 1 the projected account value was above the required minimum value except for three years. In these years employer sets aside extra contributions in a separate fund. The sum of all three contributions was equal to 13992 PLN. In year 40 , when member retired, the account value was higher than the minimum hence the extra funds were not required and remained with the employer.

Benefit amount paid from the second hybrid scheme was equal to 234963 PLN. While on average the contribution rate was $3.4 \%$ per annum, in individual years the rate could be positive or negative. In years where the rate of return was negative the employer was required to pay additional contributions into the fund. Fig. 2 presents the actual and required rate of return as well as extra contributions paid by the employer in the second hybrid scheme.

In the second type of hybrid scheme extra contribution amounts were required from the employer in years when the actual rate of investment returns achieved was negative. In the scenario this happened in 15 out of 40 scheme years. The sum of these extra contributions was equal to 42025 PLN, more than in the first hybrid scheme. Employer contributions were paid into the member's account and were paid out as a benefit to member at retirement. Fig. 3 presents the account value, split between funds accumulated from standard contributions of 3.5\% of salary and from extra employer contributions. 


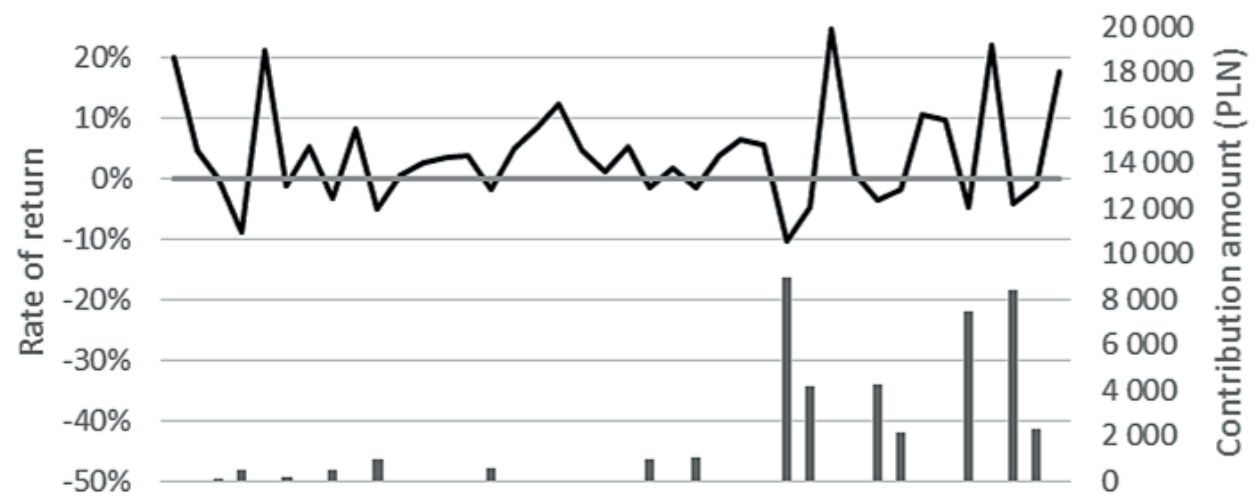



Scheme year

\section{Extra employer contribution —-Actual rate of return \\ Minimum rate of return}

Fig. 2. Actual and minimum rate of investment returns and extra contributions paid by the employer in the second hybrid scheme in each scheme year for the moderate scenario

Source: own work.



Eund accumulated from extra employer contributions

- Fund accumulated from standard contributions

Fig. 3. Account value in the second hybrid scheme in each scheme year split into fund accumulated from standard contributions and from extra employer contributions for the moderate scenario

Source: own work. 
Extra employer contributions paid into the second hybrid scheme increase the value of the account. The benefit amount at retirement (234 963 PLN) was made up in $72 \%$ of the fund accumulated from standard contributions and in $28 \%$ of the extra fund due to employer contributions.

In the second scenario, called the pessimistic one, the rates of investment returns drawn from normal distribution were lower than expected, with an average equal to $1.2 \%$. As a result, the benefit from a traditional DC scheme decreased to 88336 PLN. In the first hybrid scheme the minimum benefit equal to 148947 was paid. Fig. 4 shows the projected and required account value, as well as extra contributions paid by the employer in this scheme.
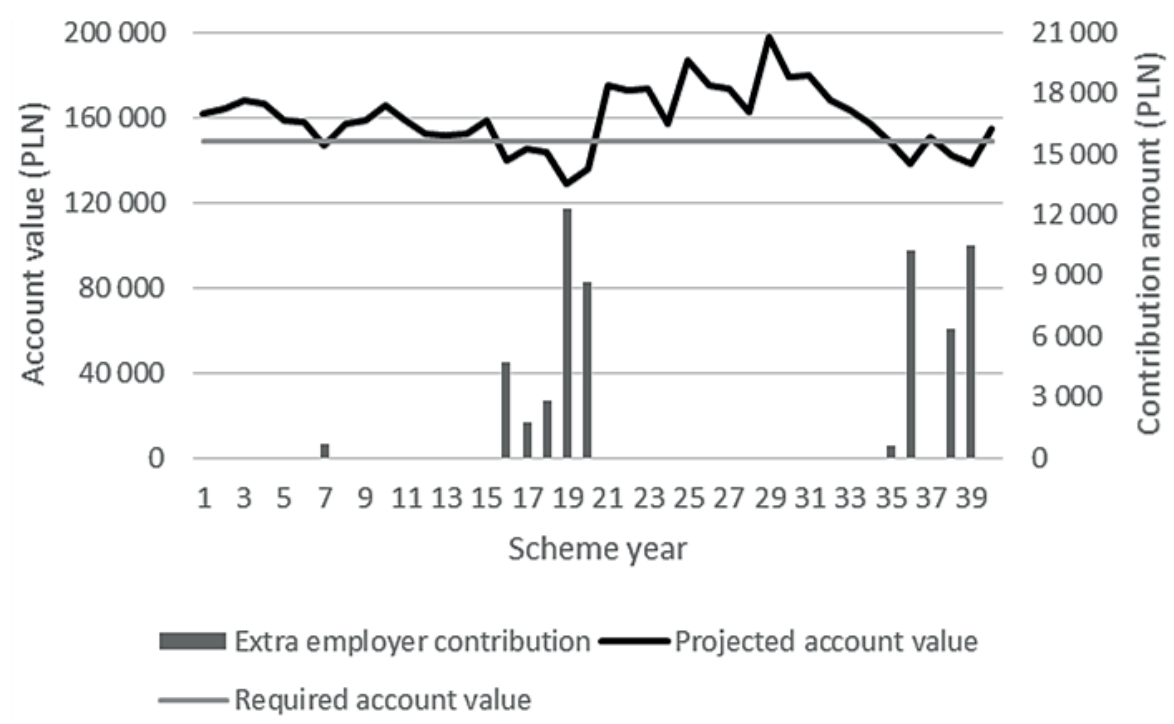

Fig. 4. Projected and required account value and extra contributions paid by the employer in the first hybrid scheme in each scheme year for the pessimistic scenario

Source: own work.

As shown in Fig. 4, in ten scheme years the projected account value fell below the required minimum. In those years extra employer contributions were paid into a separate fund. Their total was equal to 58614 PLN. At retirement, the actual account value was equal to 88336 PLN, lower than the required minimum of 148947 PLN. Hence the funds accumulated by the employer in the separate fund were used to increase the benefit to the required value.

Benefit amount paid from the second hybrid scheme was equal to 151870 PLN. Fig. 5 presents the actual and required rate of return as well as extra contributions paid by the employer. 


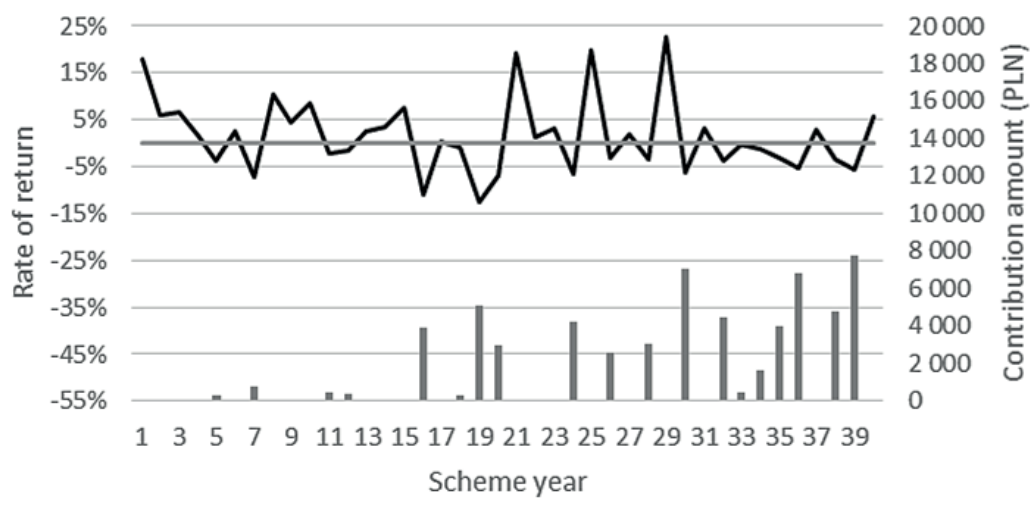

Extra employer contribution - Actual rate of return
Minimum rate of return

Fig. 5. Actual and minimum rate of investment returns and extra contributions paid by the employer in the second hybrid scheme in each scheme year for the pessimistic scenario

Source: own work.

In the pessimistic scenario extra contribution amounts were required from the employer in 19 out of 40 scheme years. The sum of these extra contributions was equal to 60936 PLN; again more than in the first hybrid scheme. Fig. 6 presents the account value, split between funds accumulated from standard contributions and from extra employer contributions.



\section{an Fund accumulated from extra employer contributions \\ - Fund accumulated from standard contributions}

Fig. 6. Account value in the second hybrid scheme in each scheme year split into fund accumulated from standard contributions and from extra employer contributions for the pessimistic scenario

Source: own work. 
The benefit amount paid from the second hybrid scheme at retirement (151 870 PLN) was made up in 58\% of the fund accumulated from standard contributions and in $42 \%$ of the extra fund due to employer contributions.

\subsection{Simulation results}

In order to investigate the two hybrid schemes further simulations of different financial scenarios were performed. Forty investment rates of return were drawn from normal distribution with mean $3 \%$ and standard deviation $8 \%$. The benefit amount payable from each scheme, as well as the sum of employer extra contributions were calculated. The number of years in which extra employer contributions were required was also noted. The process was then repeated 10000 times. The results of simulations are summarized in Table 2.

Table 2. Summary of simulation results

\begin{tabular}{|l|c|c|c|}
\hline \multicolumn{1}{|c|}{ Measure } & $\begin{array}{c}\text { Traditional DC } \\
\text { scheme }\end{array}$ & $\begin{array}{c}\text { First hybrid scheme } \\
\text { (minimum } \\
\text { account value set) }\end{array}$ & $\begin{array}{c}\text { Second hybrid scheme } \\
\text { (minimum rate } \\
\text { of return credited } \\
\text { every year) }\end{array}$ \\
\hline Mean benefit amount & 149088 PLN & 167096 PLN & 228 902 PLN \\
\hline $\begin{array}{l}\text { Mean sum of employer's extra } \\
\text { contributions }\end{array}$ & 0 PLN & 28700 PLN & 57 190 PLN \\
\hline $\begin{array}{l}\text { Mean number of years during } \\
\text { which employer had to pay extra } \\
\text { contributions }\end{array}$ & 0 & 6.6 & 13.8 \\
\hline
\end{tabular}

Source: own work.

As shown in Table 2, the mean benefit amount achieved in a traditional DC scheme with no underpin was 149088 PLN. It is close to 148947 PLN, the amount calculated using investment rate of $3 \%$ per annum and set as a minimum in the first type of hybrid scheme. This is due to the fact that whilst in the simulations the investment rates can vary every year, they are drawn from a distribution with mean equal to $3 \%$ and so their average should be fairly close to $3 \%$ as well.

Introducing an underpin increases the mean benefit amount compared to the traditional DC scheme. In the first type of hybrid scheme, where a minimum account value at retirement is defined, the mean benefit amount was 167096 PLN, an increase of $12 \%$ in comparison to the mean benefit in a DC scheme. In the second hybrid where the minimum investment rate of return applies every year the mean benefit amount was even higher - 228902 PLN, an increase of 54\% in comparison with a DC scheme.

These increases came as a result of extra employer contribution paid into the hybrid schemes due to setting of an underpin. Higher employer contributions were payable in the second hybrid scheme, where the minimum rate of return was set for 
every year. The mean sum of employer contributions over the scheme membership was 57190 PLN, and the contributions were payable on average in 13.8 years out of 40 scheme years. In the first hybrid scheme the extra employer contributions were lower, with mean sum equal to 28700 PLN, and payable on average in 6.6 out of 40 scheme years.

\section{Conclusion}

DC scheme with an underpin is a type of hybrid scheme which allows for the risk to be shared between a member and an employer. There are many forms of such a scheme, depending on how the minimum benefit is defined. Two common methods are to specify a minimum benefit amount which needs to be paid out to the member at retirement, or to set a minimum interest rate that has to be credited to member's account every year.

In this paper two models of hybrid schemes were constructed and used to compare the two methods of setting minimum benefit in a DC with an underpin scheme. In the first scheme a minimum benefit at retirement was defined by applying an interest rate of 3\% per annum to set contribution amounts. In the second scheme it was assumed that the minimum interest rate credited every year has to be $0 \%$. Simulation results show that the second scheme produces higher mean benefit amount for the member than the first scheme. In order to achieve this, the employer has to pay higher additional contributions into the scheme, and such contributions are required more frequently.

\section{References}

Blommestein H., Janssen P., Kortleve N., Yermo J., 2009, Moving beyond the 'DB vs. DC' debate: The appeal of hybrid pension plans, Rotman International Journal of Pension Management, vol. 2, issue 2, pp. 66-76.

Clark G.L., Monk A.H.B., 2006, The 'crisis' in defined benefit corporate pension liabilities. Part I: Scope of the problem, Pensions, vol. 12, no. 1, pp. 43-54.

Credit Suisse, Credit Suisse Swiss Pension Fund Index, https://www.credit-suisse.com/ch/en/ unternehmen/institutional-clients/global-custody/pensionskasse.html (access date 03.04.2018).

Davis R., 2013, The Tracker plan: A controlled risk defined contribution retirement program, The John Marshall Law Review, vol. 46, issue 3, pp. 681-718.

Guðmundsson B., Bennewitz B., Asgrímsson B.Z., Bragadóttir K.I. i Halldórsson S., 2014, Retirement savings adequacy. Measurement in Iceland, The Financial Supervisory Authority in Iceland Research Project.

GUS, 2018, Komunikat w sprawie przeciętnego wynagrodzenia w gospodarce narodowej w 2017 roku, https://stat.gov.pl/sygnalne/komunikaty-i-obwieszczenia/lista-komunikatow-i-obwieszczen/ komunikat-w-sprawie-przecietnego-wynagrodzenia-w-gospodarce-narodowej-w-2017roku, 273,5.html.

Instytut Emerytalny, 2018, 20 odston PPE vs PPK, http:/www.instytutemerytalny.pl/wp-content/ uploads/2018/02/20-ods\%C5\%82on-PPE-vs-PPK-luty-2018.pdf. 
Pugh C., Yermo J., 2008, Funding regulations and risk sharing, OECD Working Papers on Insurance and Private Pensions, No. 17, OECD Publishing.

Szczepański M., Brzęczek T., 2016, Zarzadzanie ryzykiem w pracowniczych programach emerytalnych. Uwarunkowania instytucjonalne, ekonomiczno-fiskalne i demograficzne, Polskie Towarzystwo Ekonomiczne, Poznań.

Turner J., 2014, Hybrid pensions: risk sharing arrangements for pension plan sponsors and participants, Society of Actuaries Research.

Turner J., Hughes G., 2008, Large declines in defined benefit plans are not inevitable: The experience of Canada, Ireland, the United Kingdom and the United States, Pensions Institute Discussion Paper PI-0821, Cass Business School, City University London.

Wesbroom K., Reay T., 2005, Hybrid pension plans: UK and international experience, Department for Work and Pensions Research Report 271. 